\title{
TETRANACTIN, A NEW MITICIDAL ANTIBIOTIC
}

\author{
I. ISOLATION, CHARACTERIZATION AND \\ PROPERTIES OF TETRANAGTIN
}

\author{
Kunio Ando, Hideo Oishi, Seiji Hirano, Tsuneo Okutomi, \\ KojI Suzuki, Hiroshi Okazaki, \\ Mikio Sawada and Takao Sagawa \\ Research Laboratories, Chugai Pharmaceutical Co., Ltd., \\ Toshima-ku, Tokyo, Japan
}

(Received for publication January 18, 1971)

\begin{abstract}
In our screening for pesticidal antibiotics using Azuki-bean weevil as a test insect, a new antibiotic, tetranactin, was isolated as crystalline rhombic prisms from the filter cake of the fermented broth of Streptomyces aureus strain S-3466. Tetranactin shows significant insecticidal activity against Azuki-bean weevil by the topical application method but lucks the activity by the film contact method. The adults of carmine mite are highly sensitive to the antibiotic, since $\mathrm{LC}_{50}$ for the mite is $9 \mathrm{ppm}$ by the spray method. The antibiotic inhibits the growth of gram-positive bacteria and some phytopathogenic fungi in vitro at low concentrations. Acute toxicity of tetranactin is low ; mice tolerated an intraperitoneal administration of $300 \mathrm{mg} / \mathrm{kg}$ and an oral administration of $15,000 \mathrm{mg} / \mathrm{kg}$.
\end{abstract}

A number of reports have appeared which dealed with pesticidal activity of antibiotics. It was found that aureothin ${ }^{1)}$, antimycin $\mathrm{A}^{2)}$, piericidine ${ }^{3)}$ and cycloheximide $^{4)}$ exert pesticidal activity, although the usefulness is strictly limited because of the high oral toxicity to a warm-blooded animal.

In our screening for pesticidal antibiotics using Azuki-bean weevil as a test insect, a crystalline active principle effective against the carmine mite, Tetranychus telarius, was isolated from the filter cake of the fermented broth of a soil Streptomyces strain S-3466. The active principle was named tetranactin, as it has the same chemical structure to that of a hypothetic compound, tetranactin, described by GERLACH et $a l^{5}$. This paper deals with isolation, characterization and some properties of tetranactin and identification of the producing microorganism.

\section{Identification of Producing Microorganism}

The producing organism, Streptomyces strain S-3466, was isolated from the soil collected at Tsurugashima, Saitama Prefecture, Japan. Taxonomy was carried out according to WAKSMAN ${ }^{6}$. Morphological characteristic of the strain was as follows: sporophres long, straight or wavy, but not forming spirals; spherical to oval, 0.7 $0.8 \mu \times 1.0 \mu$. Morphological characteristics on various media are listed in Table 1. The strain S-3466 is closely related to Streptomyces aureus WAKSMAN et HENRICI, although the characteristics are slightly different from those described by WAKSMAN ${ }^{6}$. 
Table 1. Morphological characteristics of Streptomyces aureus S-3466 on various media

\begin{tabular}{|c|c|c|c|c|}
\hline Medium & Growth & Aerial mycelium & Soluble pigment & \\
\hline Sucrose nitrate agar & Thin & $\begin{array}{l}\text { Thin, powdery, } \\
\text { cream colored }\end{array}$ & None & \\
\hline Malate glycerol agar & $\begin{array}{l}\text { Good, } \\
\text { cream colored }\end{array}$ & $\begin{array}{l}\text { Powdery, } \\
\text { yellowish white }\end{array}$ & Pale brown & \\
\hline $\begin{array}{l}\text { Glucose-asparagine } \\
\text { agar }\end{array}$ & $\begin{array}{l}\text { Good, } \\
\text { pale yellow }\end{array}$ & $\begin{array}{l}\text { Powdery, } \\
\text { yellowish white }\end{array}$ & Pale yellow & \\
\hline $\begin{array}{l}\text { Glycerol-asparagine } \\
\text { agar }\end{array}$ & Good & $\begin{array}{l}\text { Powdery, } \\
\text { pale yellow }\end{array}$ & $\begin{array}{l}\text { Pale yellowish } \\
\text { brown }\end{array}$ & \\
\hline Nutrient agar & Good & Buff colored & $\begin{array}{l}\text { Pale yellowish } \\
\text { brown }\end{array}$ & \\
\hline Bennetr's agar & $\begin{array}{l}\text { Good wrinkled, } \\
\text { raised center }\end{array}$ & Yellowish gray & $\begin{array}{l}\text { Dark yellowish } \\
\text { brown }\end{array}$ & \\
\hline Starch agar & $\begin{array}{l}\text { Moderate, } \\
\text { colorless }\end{array}$ & Yellowish white & $\begin{array}{l}\text { Pale yellowish } \\
\text { orange }\end{array}$ & $\begin{array}{l}\text { Hydrolysis: } \\
\text { good }\end{array}$ \\
\hline Potate plug & $\begin{array}{l}\text { Abundant, } \\
\text { wrinkled, } \\
\text { yellowish brown }\end{array}$ & $\begin{array}{l}\text { Light brownish } \\
\text { gray }\end{array}$ & & \\
\hline Nitrate & Flocculent & & & $\begin{array}{l}\text { Reduction } \\
\text { to nitrite }\end{array}$ \\
\hline Gelatin agar & $\begin{array}{l}\text { Surface growth } \\
\text { moderate }\end{array}$ & White & Brown & $\begin{array}{l}\text { Liquefaction: } \\
\text { slow } \\
\text { Crateriform }\end{array}$ \\
\hline Litmus milk & Good, ring & & & $\begin{array}{l}\text { Coagulation } \\
\text { and peptoniza- } \\
\text { tion: weak }\end{array}$ \\
\hline $\begin{array}{l}\text { Starch peptone beef } \\
\text { agar }\end{array}$ & Good, wrinkled & $\begin{array}{l}\text { Pale yellowish } \\
\text { brown }\end{array}$ & $\begin{array}{l}\text { Dark yellowish } \\
\text { brown }\end{array}$ & \\
\hline $\begin{array}{l}\text { Dextrin casein digest } \\
\text { agar }\end{array}$ & $\begin{array}{l}\text { Wrinkled, } \\
\text { yellowish brown }\end{array}$ & Brownish white & $\begin{array}{l}\text { Dark yellowish } \\
\text { brown }\end{array}$ & \\
\hline Cellulose-asparagine & None & & & $\begin{array}{l}\text { Hydrolysis: } \\
\text { none }\end{array}$ \\
\hline Invertase & & & & Negative \\
\hline
\end{tabular}

The strain S-3466 was compared with S. aureus IAM 0092, an original strain isolated by WAKSman and deposited in American Type Culture Collection (ATCG 3309).

\section{Production and Isolation of Tetranactin}

In our screening for pesticidal antibiotics, soil streptomyces strains isolated were aerobically grown for 4 days at $28^{\circ} \mathrm{C}$ in a medium composed of $(\mathrm{w} / \mathrm{v}, \%)$; glucose 2 , soybean meal 2, glycerol 2, peptone 0.2 , yeast extract 0.2 , beaf extract $0.2, \mathrm{KH}_{2} \mathrm{PO}_{4}$ $0.1, \mathrm{MgSO}_{4} \cdot 7 \mathrm{H}_{2} \mathrm{O} 0.05$ and $\mathrm{CaCO}_{3} 1$ (pH, not adjusted). Acetone extracts of the filter cake of the fermented broth were directly applied to the test insect, Azuki-bean weevil (Callosobruchus chinensis). An extract of streptomyces strain S-3466 exerted significant and reproducible insecticidal activity in the screening. The extract showed several spots when subjected to preparative thin-layer chromatography, but only one spot ( $\mathrm{Rf} 0.6$ ) possessed insecticidal activity.

Fractionation and isolation of the active principle is shown in Fig. 1. S. aureus strain S-3466 was aerobically grown for 3 days at $28^{\circ} \mathrm{C}$ in a jar fermentor of 100 -liter volume containing 60-liter medium. The medium composition was the same as in the screening. The jar was aerated at a rate of 30 liters/minute and agitated at 250 r.p.m. 
The fermented broth was filtered with Celite. The filter cake obtained was extracted with acetone overnight at room temperature. The acetone extract (15 liters) was concentrated in vacuo to remove acetone and the resulting suspension was re-extracted with ethylacetate $(2 \times 3$ liters). The ethylacetate layer was dehydrated with anhydrous sodium sulfate and then concentrated in vacuo to a tarry brown residue (120 g) which represented more than $90 \%$ of the insecticidal activity present in the original acetone extract. The active principle was isolated by chromatography of the tarry oil on a $3 \mathrm{~cm} \times 75 \mathrm{~cm}$ silica gel column. The column was first eluted with $n$-hexane ( 1 liter) yielding an oily residue which was largely triglyceride and was inactive against the test insect. Then the column was eluted with a mixture of $n$-hexane and acetone $(1: 1$, 1 liter). Fatty acids recovered from the eluate were also inactive against the test insect. Finally the column was eluted with ethylacetate (1 liter) to yield a colorless oil with insecticidal activity $(18 \mathrm{~g})$. The oil crystallized as large rhombic prisms from $n$-hexane at $-10^{\circ} \mathrm{C}$. However, thin-layer chromatography on silica gel (Table 2) indicated the presence of three components even after repeated recrystallization. The main component with the lowest $\mathrm{Rf}$ was named tetranactin. Tetranactin was separated from the other two components by silica gel column chromatography as shown in Fig. 2.
Fig. 1. Extraction and isolation of tetranactin

Azuki bean weevil, Callosobruchus chinensis, was used as a test insect during the course of isolation. Dipping method was used for activity check.

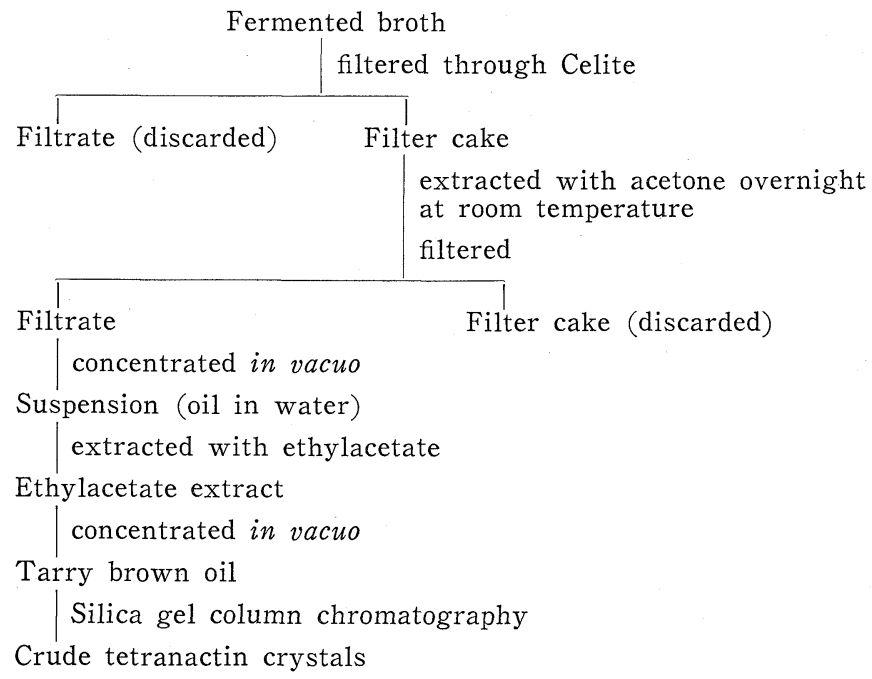

Fig. 2. Separation of tetranactin from two other macrotetrolides

Crude tetranactin crystals

Silica gel column chromatography (E. Merck, Unter $0.08 \mathrm{~mm}, 300 \mathrm{~g}$ was used for separation of $2 \mathrm{~g}$ crude tetranactin.) eluted with $\mathrm{CHCl}_{3}$ - ethylacetate $(2: 1)$

Component A eluted with $\mathrm{CHCl}_{3}$ - ethylacetate $(1: 1)$

Component B eluted with ethylacetate Tetranactin

Table 2. Rf values of each component on thin-layer chromatograms.

\begin{tabular}{|c|c|c|c|}
\hline \multirow{2}{*}{ Solvent systems } & \multicolumn{3}{|c|}{ Rf of each component } \\
\hline & $\begin{array}{c}\text { Component } \\
\text { A }\end{array}$ & $\begin{array}{c}\text { Component } \\
\text { B }\end{array}$ & Tetranactin \\
\hline Benzene - acetone $(4: 1)$ & 0.37 & 0.25 & 0.12 \\
\hline $\begin{array}{l}\mathrm{CHCl}_{3} \text { - ethylacetate } \\
\qquad(1: 2)\end{array}$ & 0.60 & 0.48 & 0.31 \\
\hline $\begin{array}{r}n \text {-Hexane-diethylether } \\
(1: 2)\end{array}$ & 0.42 & 0.32 & 0.21 \\
\hline
\end{tabular}




\section{Physicochemical Properties of Tetranactin}

Tetranactin readily crystallized as rhombic prisms from acetone, m.p. $105 \sim 106^{\circ} \mathrm{C}$, $[\alpha]_{\mathrm{D}}^{23.5} 0^{\circ}$ ( $c$ 1, chloroform). The following reactions were all negative; FeHLING, Tollens, carbazole, Elson-Morgan and ninhydrin. The antibiotic is readily soluble in most organic solvents such as $n$-hexane, cyclohexane, benzene, chloroform, diethylether, acetone, ethylacetate and alcohols, but insoluble in water. Elementary analysis showed C $66.75 \%, \mathrm{H} 9.13 \%$; halogens, nitrogen and sulf ur were not detected. The antibiotic showed no ultraviolet absorption maxima in the region of $200 \sim 400 \mathrm{~m} \mu$. Infrared absorption (IR) spectrum is shown in Fig. 3. The IR spectrum indicated the presence of ester and ether as functional groups which are characteristic for the class macrotetrolide antibiotic. The IR spectrum closely resembles that of nonactin ${ }^{7}$, the first macrotetrolide isolated. However, tetranactin is distinguishable from nonactin and other macrotetrolides ${ }^{7,8)}$ by its physicochemical properties.

Fig. 3. Infrared absorption spectrum of tetranactin (nujol).

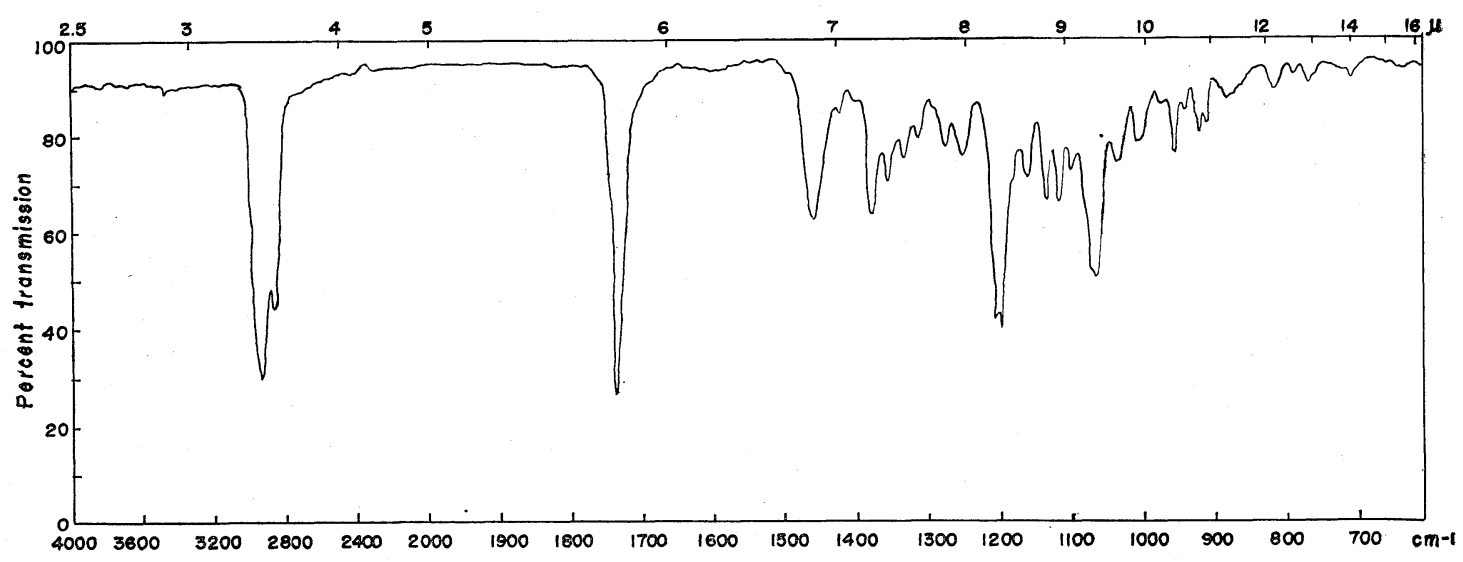

Biological Properties of Tetranactin

Table 3 shows the insecticidal activity of tetranactin against the female adults of Azukibean weevil, an insect used in the screening. Mortality was $100 \%$ at a dose of $1.5 \mu \mathrm{g} /$ insect when topically applied. However, tetranactin was inactive in the filter paper method, indicating neither vapor nor penetration through legs to active sites were involved in the insecticidal activity. For insecticidal activity tetranactin must be directly applied to the insect.

Table 4 shows the miticidal activity of tetranactin and the other two components against the adults of carmine mite. The $L C_{50}$ values calculated are $9.6 \mathrm{ppm}$ for component $\mathrm{A}$,
Table 3. Insecticidal activity of tetranactin against the female adults of Azuki-bean weevil, Callosobruchus chinensis

\begin{tabular}{|c|c|c|c|c|}
\hline \multirow{2}{*}{$\begin{array}{l}\text { Topical } \\
\text { application } \\
\text { method }\end{array}$} & \multicolumn{4}{|c|}{ Dose $(\mu \mathrm{g} /$ insect $)$} \\
\hline & 0.25 & 0.50 & 1.00 & 1.50 \\
\hline Mortality (\%) & 0.0 & 10.3 & 84.8 & 100.0 \\
\hline $\begin{array}{l}\text { Application } \\
\text { method }\end{array}$ & \multicolumn{2}{|c|}{ Dose } & \multicolumn{2}{|c|}{$\begin{array}{c}\text { Mortality } \\
(\%)\end{array}$} \\
\hline $\begin{array}{l}\text { Filter paper } \\
\text { method }\end{array}$ & \multicolumn{2}{|c|}{$\begin{array}{l}2 \mathrm{mg} / \text { filter } \\
\text { paper }\end{array}$} & & 0 \\
\hline $\begin{array}{l}\text { Film contact } \\
\text { method }\end{array}$ & \multicolumn{2}{|c|}{$\begin{array}{l}2 \mathrm{mg} / \text { petri } \\
\text { dish }\end{array}$} & & 45 \\
\hline
\end{tabular}

Fifty to a hundred of the female adults of Callosobruchus chinensis (English, Azuki-bean weevil. Japanese, Azuki zomushi) were used in each dose. Diameters of filter paper and petri dish were $9 \mathrm{~cm}$. Mortality was observed 48 hours after applications. 
$10.3 \mathrm{ppm}$ for component $\mathrm{B}$ and 9.3 ppm for tetranactin. These values are comparable to those of synthetic organic miticides.

As can be seen in Tables 5 and 6 , tetranactin inhibits the growth of gram-positive bacteria and phytopathogenic fungi by the agar dilution method. The antibiotic, however, formed very small growth inhibitory

zones $(<12 \mathrm{~mm})$ in the agar diffusion
Table 4. Miticidal activity of tetranactin and structurally related macrotetrolides

\begin{tabular}{l|c|c|c|c|c|c}
\hline & \multicolumn{4}{|c|}{ Mortality (\%) at each } & \multirow{2}{*}{$\mathrm{LC}_{50}$} \\
\cline { 2 - 6 } & 40 & 20 & 10 & 5 & 2.5 & $(\mu \mathrm{g} / \mathrm{ml})$ \\
\hline Tetranactin & 86.5 & 75.9 & 52.5 & 33.6 & 32.0 & 9.2 \\
Component A & 81.5 & 72.7 & 46.5 & 39.4 & 34.8 & 9.6 \\
Component B & 76.0 & 65.1 & 50.9 & 37.2 & 43.5 & 10.8 \\
\hline
\end{tabular}

Fifty to a hundred adults of carmine mite, Tetranychus telarius, were used at each concentration. The aqueous suspensions of the three were sprayed onto the leaves of the host plant, kidney bean, with the mites and mortality was observed 48 hours after spray.

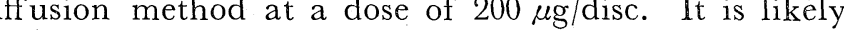
that the small growth inhibitory zones formed by tetranactin are due to the insolubility in water. Gram-negative bacteria except Shigella sonnei were insensitive to

Table 5. Antimicrobial spectrum of tetranactin

\begin{tabular}{l|c} 
Microorganisms tested & $\begin{array}{c}\text { Minimum } \\
\text { inhibitory } \\
\text { concentration } \\
(\mu \mathrm{m} / \mathrm{ml})\end{array}$ \\
\hline Arthrobacter simplex & 0.9 \\
Brevibacterium ammoniagenes & 0.1 \\
Microbacterium flavum & 0.9 \\
Micrococcus flavus & 0.9 \\
Serratia marcescens & $>24.3$ \\
Staphylococcus aureus & $<0.1$ \\
Sarcina lutea & 0.3 \\
Bacillus megaterium & 0.9 \\
Bacillus cereus & 0.9 \\
Bacillus subtilis & 0.9 \\
Bacillus roseus & 0.9 \\
Bacillus circulans & 0.1 \\
Bacillus firmus & 0.9 \\
Shigella sonnei & $>0.1$ \\
Aerobacter aerogenes & $>24.3$ \\
Agrobacter radiobacter & $>24.3$ \\
Alcaligenes faecalis & $>24.3$ \\
Escherichia coli & $>24.3$ \\
Salmonella typhosa & $>24.3$ \\
Klebsiella pneumoniae & $>24.3$ \\
Proteus vulgaris & $>24.3$ \\
Pseudomonas aeruginosa & $>24.3$ \\
Pseudomonas ovalis & $>24.3$ \\
Xanthomonas oryzae & $>24.3$ \\
Xanthomonas citri & $>24.3$ \\
Xanthomonas phaecalis & $>24.3$ \\
Erwinia aroidea & $>24.3$ \\
Corynebacterium michiganensis & Mycobacterium. \\
Mycobacterium tuberculosis & mediumd \\
Mycobacterium 607 & inoculation. \\
\hline The growth was observed 72 hours after inoculation \\
Mycobacterium was grown on Kirchner \\
the growth was observed 14 days after
\end{tabular}

Table 6. Antimicrobial spectrum of tetranactin against fungi.

\begin{tabular}{|c|c|}
\hline Fungi tested & $\begin{array}{c}\text { Minimum } \\
\text { inhibitory } \\
\text { concentrations } \\
(\mu \mathrm{g} / \mathrm{ml})\end{array}$ \\
\hline Candida albicans & $>24.3$ \\
\hline Candida krusei & 8.1 \\
\hline Cryptococcus neoformans & $>24.3$ \\
\hline Hansenula anomala & 24.3 \\
\hline Saccharomyces cerevisiae & $>24.3$ \\
\hline Cercospora oryzae & $>24.3$ \\
\hline Gibberella saubinetii & 8.1 \\
\hline Gibberella fujikuroi & $>24.3$ \\
\hline Botrytis cinerea & 24.3 \\
\hline Botrytis tulipae & $>24.3$ \\
\hline Sclerotinia arachidis & $>24.3$ \\
\hline Fusarium lini & $>24.3$ \\
\hline Cochliobolus miyabeanus & 0.9 \\
\hline Macrosporium bataticola & 8.1 \\
\hline Alternaria kikuchiana & $>24.3$ \\
\hline Corynespora vignicola & $>24.3$ \\
\hline Glomerella cingulata & $>24.3$ \\
\hline Glomerella lagenarium & $>24.3$ \\
\hline Cladosporium fluvum & $>24.3$ \\
\hline Colletotrichum atromentarium & $>24.3$ \\
\hline Rosedlinis necatrix & $>24.3$ \\
\hline Piricularia oryzae & 2.7 \\
\hline Pellicularia sasakii & 8.1 \\
\hline Gloeosporium kaki & $>24.3$ \\
\hline Helminthosporium sesanum & $>24.3$ \\
\hline Rhizoctonia solani & 0.9 \\
\hline Phoma citricarpa & $>24.3$ \\
\hline Pestalotia diospyri & $>24.3$ \\
\hline Mycospherella arachidicola & $>24.3$ \\
\hline Aspergillus oryzae & $>24.3$ \\
\hline Aspergillus fumigatus & $>24.3$ \\
\hline Penicillium citrinum & $>24.3$ \\
\hline Aspergillus niger & $>24.3$ \\
\hline
\end{tabular}


tetranactin. It is noteworthy that $S$. sonnei resistant to streptomycin, chloramphenicol, tetracyclines and sulfonamides is inhibited at less than $0.03 \mu \mathrm{g} / \mathrm{ml}$.

Acute toxicity of tetranactin is low; the $\mathrm{LD}_{50}$ is $>300 \mathrm{mg} / \mathrm{kg}$ (mice, i.p.) and $>15,000 \mathrm{mg} / \mathrm{kg}$ (mice, p.o.). Thus, tetranactin is a potential miticidal agent in view of the low toxicity to a warm-blooded animal and remarkable activity.

Elucidation of the structure and evaluation of the miticidal activity will be presented in subsequent papers.

\section{References}

1) Oishi, H.; T. Hosokawa, T. Okutomi, K. Suzuki \& K. Ando: Pesticidal activity of aureothin. Agr. Biol. Chem. $33:$ 1790 1791, 1969

2) Kido, G. S. \& E. Spinalski: Antimycin A, an antibiotic with insecticidal and miticidal properties. Science $112: 172 \sim 173,1950$

3) Tamura, S.; N. Takahashi, S. Mryamoto, R. Mori, S. Suzuki \& J. Nagatsu: Isolation and physiological activity of piericidine A, a natural insecticide produced by Streptomyces. Agr. Biol. Chem. $27: 576 \sim 582,1963$.

4) Harries, F. H.: Further studies of effects of antibiotics and other compounds on fecundity and mortality of the two-spotted spider mite. J. Econ. Entomol. $61: 12 \sim 14,1968$

5) Gerlach, H.; R. Hütter, W. Keller-Schierlein, J. Seibl \& H. Zähner : Stoffwechselprodukte von Mikroorganismen. I. Neue Makrotetrolide aus Actinomyceten. Helv. Chim. Acta 50 : 1782 1793, 1967

6) Waksman, S. A.: The actinomycetes. Vol. 2, The Williams \& Wilkins Co., 1961

7) Corbaz, R.; L. Etthlinger, E. Gäumann, W. Keller-Schierlein, F. Kradolfer, L. Neipp, V. Prelog \& H. Z̈̈hner: Metabolic products of actinomycetes. III. Nonactin. Helv. Chim. Acta $45: 1445 \sim 1448,1955$

8) Beck, J.; H. Gerlach, V. Prelog \& W. Voser: Metabolic products of actinomycetes. XXXV. Structures of monactin, dinactin and trinactin. Helv. Chim. Acta $45: 620 \sim 630,1962$ 